\title{
Nutrient composition of tall fescue pasture forage free of or infested with Acremonium coenophialum
}

\author{
JC Waller, HA Fribourg, JH Reynolds, RB Graves, CL Walker, KD Gwinn
}

University of Tennessee, Knoxville, TN 37901-1071, USA

Infestation of tall fescue (Festuca arundinacea) 'KY-31' pastures with the endophytic fungus $A$. coenophialum is associated with substantial economic reduction in grazing livestock production (Stuedemann \& Hoveland, 1988, J Prod Agric, 1, 39-44 ; Fribourg et al, 1991, Fourrages, 126, 209-223). Losses due to tall fescue toxicosis are estimated to approach one billion dollars annually for beef cattle in the eastern USA (Fribourg et al, 1991, TN Farm \& Home Sci, 160, 30-37). Several studies have shown that the use of endophyte-free (E-) cultivars leads to improved cattle performance (increased weight gain, milk production, and conception rate) compared to endophyte infected $\left(E^{+}\right)$tall fescue. This study was to determine whether the reduced performance of growing steers grazing $E+$ tall fescue pastures is related to nutrient composition of the forage.

Two treatments were established near Knoxville $\left(35^{\circ} 49^{\prime} \mathrm{N}, 83^{\circ} 59^{\prime} \mathrm{W}\right)$ in a $1989-1994$ study to compare $80 \% \mathrm{E}+\mathrm{KY}-31$ tall fescue pastures with $E-K Y-31$ pastures. Treatments were replicated twice in a randomised complete block design, and experimental units measured 1.2 ha. Experimental steers grazed from age 8 mo each fall until age 18 mo the next year; grazing was done each year for 4 fall-winter seasons, early November to midJanuary, and for 4 spring-summer seasons, mid-March to early September. Additional grazing animals were used when forage growth was rapid, to keep forage height between 10 and $15 \mathrm{~cm}$, resulting in 800 to $1500 \mathrm{~kg} / \mathrm{ha}$ of available forage throughout. Levels of endophyte infestation were monitored yearly and remained constant. Forage samples from 5 strips $\left(1.62 \mathrm{~m}^{2}\right)$ and 5 protected cages $\left(0.65 \mathrm{~m}^{2}\right)$ per ha were collected with a rotary mower at 21-d intervals and at the beginning and end of each grazing season. Samples were dried at $60^{\circ} \mathrm{C}$ in a forced draft oven, ground to pass through a 2-mm Wiley mill sieve, then through a $1-\mathrm{mm}$ Cyclone mill sieve. The tall fescue calibration equations (using 275 other samples) were established for a Pacific Scientific model 6250 monochromator with Infrasoft International NIRS-2 software. The more than 550 samples were analysed for crude protein (CP), acid detergent fiber (ADF), and neutral detergent fiber (NDF).

Forage nutrient composition varied with age and ambient conditions, as expected, from season to season and within season. Weight gains of steers were significantly different $(P>0.05)$ each spring-summer between treatments. However, there were no significant differences in CP, ADF, and NDF between the two tall fescue treatments when variability due to year, season, and date of sampling was removed. Samples from cages were not significantly different in nutrient composition from strip samples when collected at 21-d intervals.
Tall fescue

(strips)

$\mathrm{E}^{-}$

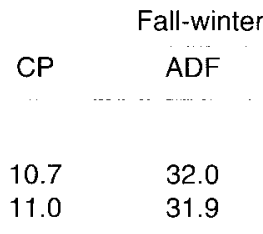

NDF

$\%$ (dry matter basis)

57.8

57.8
Spring-summer

ADF NDF

33.0

62.1

61.0 